\title{
A Federal Spain in a Federal Europe
}

\author{
Guy Verhofstadt
}

I have always been a profound admirer of Spanish democracy, but especially since February 23, 1981. On that dramatic day, Colonel Antonio Tejero attempted a coup d'état against the young democratic regime. In his acclaimed book Anatomía de un instante (The Anatomy of a Moment), Javier Cercas describes how, under the threat of Tejero's pistol, three Spanish political leaders sat upright in their seats, refusing to hide under their benches. Not one of them Communist Party leader Santiago Carrillo, Adolfo Suárez, the first prime minister of post-Franco, democratic Spain, and Suárez's deputy, General Gutiérrez Mellado - blinked. It was an act of courage and determination that anchored democracy forever in the soul of Spain. Under the pistol of Tejero, Spanish democracy was born.

Today, 36 years later, Spanish democracy must steel itself once more if it is to overcome the deep division created by the Catalan regional government's unconstitutional bid to secede from the Spanish Republic. Today's democrats will need to show the same disciplined determination as Carillo, Suárez, and Mellado to resolve Spain's gravest political crisis since Tejero's attempted coup.

Spain's democrats must not believe that law and the judiciary can address all of the problems with Catalonia on their own. Certainly, the Spanish authorities will not overcome the crisis with police violence, even though the national government's efforts to halt the Catalan independence referendum were based on a court ruling.

What is needed now is a renewed political vision, an inclusive dialogue. Realistically, that vision can only be of a multicultural, multilingual, federal state embedded in a multicultural, multilingual, and federal Europe.

Catalan separatists were wrong to call an illegal referendum. No one can govern democratically without the rule of law. But it is also true that the existing legal framework is incapable of healing such deep political division. Sustained dialogue - the real strength of effective politicians and statesmen - between Spain's leaders and Catalonia's separatists is the only way to find solutions. I do not believe it is in the interests of Catalonia's people to pursue separatism at all costs. The fact that the referendum clearly violated the Spanish Constitution is not the main reason that I could not support it. The point for me is that the referendum lacked any democratic legitimacy whatsoever. It was clear well in advance that a majority of Catalans, recognizing the illegal nature of the exercise, would not participate. Indeed, from all the evidence that has emerged, it seems likely that a majority of Catalans, including those who stayed home, are against separation.

By refusing to establish a minimum turnout threshold for a secession vote to be declared valid, the pro-independence leaders of Catalonia's regional government revealed how they would portray the result before anyone cast a ballot. Their deceptive tactic reflected a disturbing willingness to manipulate their citizens. To declare independence on the basis of a defective referendum was a politically irresponsible act of contempt for democratic norms.

Such irresponsibility is a threat not only for Spain, and not just for Europe, but also for 
Catalonia itself. As with so many referendums, this fake independence vote has opened a deep fracture in Catalan society. Families and neighbors now stand divided - bitterly so in many cases. The only people who will benefit from this legal charade, as we know, are those who want to destroy the EU and who have already started to exploit the cause of Catalonian independence for their own ends. It is therefore vital that all the people of Spain act to stop any further escalation and instead begin negotiating. The future of Catalonia, and the future of my own Flemish community in Belgium, where some are also agitating for independence, lies not in brutal separation, but in cooperation within federal structures, in a federal Europe.

The experience of the Basque country is illustrative in this regard. Under Spain's democracy, the Basques have developed their region for the benefit of its inhabitants, not only defeating terrorism, but also reinventing themselves as proud and autonomous.

In politics, there is no shame in compromise. Quite the contrary: When a choice must be made between a constructive bargain and ideological purity, it is always better to choose the path of unity, however small the steps may be.

In her famous book The March of Folly, the American historian Barbara Tuchman warned against the urge to "throw away the greater for the less" and to "pursue the unworkable at the sacrifice of the possible." Leaders on both sides of Spain's secession crisis would be wise to heed her words. 